\title{
ROMANIA: THE EFFICIENCY AND PERSPECTIVE FOR TRANSPORT OF PASSENGERS ON RAILWAYS
}

\author{
Clara Elena Mut ${ }^{1}$ \\ Ciprian Beniamin Benea ${ }^{2}$ \\ Adrian Negrea ${ }^{3}$ \\ Săcară-Onita Adina ${ }^{4}$ \\ Catarig Andra ${ }^{5}$
}

DOI: https://doi.org/10.31410/LIMEN.2020.329

\begin{abstract}
As main premises related to transport generally indicate, all the more so in Europe, where the prosperity of continent will depend on the capacities of all European regions to maintain full integration in the world economy, competitively; and efficient transport systems are cornerstones to achieve this. In this perspective, this paper is an analysis of the main performance parameters which are necessary to sustain an efficient railway transport system at the national level. The study is based on data and information centralized by The Authority for Railway Reform (Autoritatea pentru Reforma Feroviara-ARF) during three years, when there were in force contracts of public transport services related to people transport on railways (January 2016-September 2019).
\end{abstract}

Keywords: Railway transport, Land transport, Sustainable future.

\section{INTRODUCTION}

7 he railway transport system is a very important resource for a national economy benefitting from a series of natural advantages as great transport capacity, safety, energy efficiency, less harmful for the environment. These advantages place railway transport in a position with greater competitiveness related to costs in the structure of the transport system in general. Only water transport - maritime and inland waterways - is cheaper. As a direct consequence, the economic efficiency of a national transport system is bigger when railway transport is better valued and used.

With all these arguments for railway transport development, the market of land transport is negatively influenced by economic distortions giving an incorrect competitive advantage to road transport face-to-face with railway transport. The main way these distortions act is related to the way these two modes of transport receive public financing. This differentiation is observable in the number of funds to be allocated from public money, or it can be observable in the way the recovering money policy of public costs from the clients of different modes of transport is established. What all types of transport have in common is that they all generate great costs which are used to cover the building and maintenance related to transport infrastructures and the acquisition and maintenance of the necessary means of transport. Having in mind that transports are key components of a national economy, the dimension of

SC Interregional SRL - (private railway transport operator), Romania University of Oradea, Strada Universității nr. 1, Oradea 410087, Romania University of Oradea, Strada Universității nr. 1, Oradea 410087, Romania University of Oradea, Strada Universității nr. 1, Oradea 410087, Romania University of Oradea, Strada Universității nr. 1, Oradea 410087, Romania 
these great costs determines that a great part of costs generated by the transport system to be covered from public financing sources.

Public financing of railway transport is directed at two main areas:

- railway infrastructure, because the owner is the state and it must provide the necessary funding for development, maintenance, and renewal of railway infrastructure;

- public services related to peoples' transport on railways, when the state imposes a maximum limit on tariffs demanded for public transport services, assuming to compensate the differences between railway transport operators incomes and their operative costs, adding to this difference a profit share of $3 \%$.

\section{THE EVOLUTION OF FINANCIAL COMPENSATION AT THE NATIONAL LEVEL}

In the following table 1, it is presented the financial compensation of railway transport companies from public funds to support passengers' transport on railways and the quantum of facilities given to specific social categories of passengers (retired persons, war veterans, students, revolutionaries, and other special categories). The passengers' railway transport operators in Romania are National Railway Transport Company for Passengers (SNTCF), CFR Calatori, SC Regio Calatori SRL, SC Interregional Calatori SRL, SC Transferoviar Calatori SRL, SC Softrans SRL, SC Astra Trans Carpatic SRL.

Graph 1. The Evolution of Public Subsidies for 2016-2019 (thousands RON)

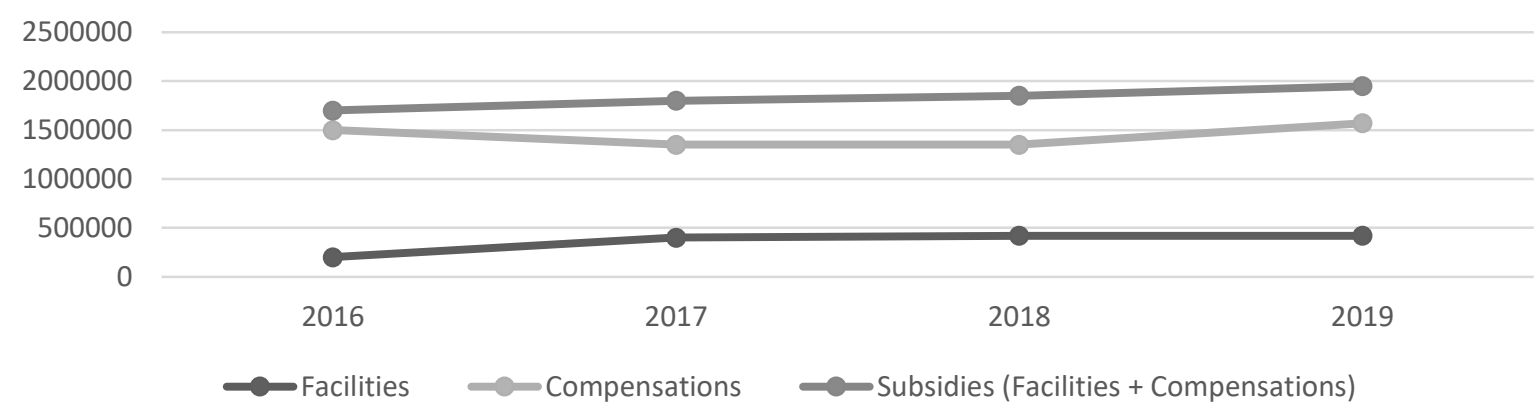

Source:http://arf.gov.ro/web/wp-content/uploads/2019/10/Octombrie-2019-Studiu-analizaindicatori-OTF, p. 3

The statistical data indicates a positive funding evolution. For the 2016-2017 period there was a contraction of national compensation quantum, while the total amount of subsidy and facilities had been relatively stable. Starting with 2017, there was a noticeable slow increase, since gratuities for students using railway transport were introduced.

Table 1. Compensation Allotted to Railway Transport Operators (OTF) for 2016-2019 (thousands RON)

\begin{tabular}{|l|r|r|r|r|}
\hline \multicolumn{1}{|c|}{ OTF/Year } & \multicolumn{1}{c|}{$\mathbf{2 0 1 6}$} & \multicolumn{1}{c|}{$\mathbf{2 0 1 7}$} & \multicolumn{1}{c|}{$\mathbf{2 0 1 8}$} & \multicolumn{1}{c|}{$\mathbf{2 0 1 9}$} \\
\hline SNTFC CFR Calatori & $1,060,767,880$ & $1,091,123,810$ & $1,071,738,310$ & $1,141,670,796$ \\
\hline Regiotrans & $141,549,867$ & $125,590,237$ & - & - \\
\hline Regio Calatori & - & $6,867,518$ & $138,176,591$ & $146,820,415.30$ \\
\hline Transferoviar Calatori & $74,471,615.65$ & $69,651,900$ & $75,068,265$ & $83,492,077.50$ \\
\hline Interregional Calatori & $23,615,425.27$ & $25,525,150$ & $31,273,279$ & $38,390,999.40$ \\
\hline Astra Trans Carpatic & & & $9,615,260$ & $14,092,480.60$ \\
\hline Softrans & $11,680,359$ & $9,414,183.97$ & $8,999,663$ & $11,533,231.20$ \\
\hline
\end{tabular}




\begin{tabular}{|c|r|r|r|r|}
\hline TOTAL & $1,312,085,146$ & $1,328,172,798$ & $1,334,871,368$ & $1,436,000,000$ \\
\hline
\end{tabular}

Source: http://arf.gov.ro/web/wp-content/uploads/2019/10/Octombrie-2019-Studiuanaliza-indicatori-OTF, p. 4

It is important to mention that yearly differences regarding compensation's value directed to railway transport operators of passengers in Romania depend on performance indicators reached by each operator and it is influenced by train $/ \mathrm{km}$, passengers $/ \mathrm{km}$ and minimum mandatory incomes to be achieved.

\section{The evolution of train $/ \mathrm{km}$ indicator}

The diminution of train-km indicator in 2018 related to 2017 is a direct consequence of a $10 \%$ reduction of compensation introduced in October 2017 because of Romania's national budget rectification through government's ordinance no. 63/September 13, 2017, which had allotted for compensation purposes for the year 2018 a quite similar amount as it had been in 2017 .

Table 2. The Evolution of Train-Km Indicator for 2016-2019

\begin{tabular}{|l|r|r|r|r|}
\hline \multicolumn{1}{|c|}{ Transport Railway Operator } & \multicolumn{1}{c|}{$\mathbf{2 0 1 6}$} & \multicolumn{1}{c|}{$\mathbf{2 0 1 7}$} & \multicolumn{1}{c|}{$\mathbf{2 0 1 8}$} & \multicolumn{1}{c|}{$\mathbf{2 0 1 9}$} \\
\hline SNTFC CFR CALATORI & $52,146,260$ & $52,229,969.20$ & $49,881,389.40$ & $50,206,425.20$ \\
\hline REGIOTRANS & $5,993,803.60$ & $5,618,640.60$ & & \\
\hline REGIO CALATORI & 0 & $327,452.70$ & $6,148,266$ & $6,040,672.30$ \\
\hline TRANSFEROVIAR CALATORI & $3,273,320$ & $3,404,763.90$ & $3,436,753.10$ & $3,478,431$ \\
\hline INTERREGIONAL CALATORI & $1,160,330$ & $1,448,714$ & $1,488,369.70$ & $1,734,540.20$ \\
\hline ASTRA TRANS CARPATIC & & & $612,593.20$ & $858,984.20$ \\
\hline SOFTRANS & $643,232.39$ & $636,276.30$ & $544,904.70$ & $646,331.80$ \\
\hline \multicolumn{1}{|c|}{ TOTAL } & $\mathbf{6 3 , 2 1 6 , 9 4 5 . 9 9}$ & $\mathbf{6 3 , 6 6 5 , 8 1 6 . 7 0}$ & $\mathbf{6 2 , 1 1 2 , 2 7 6 . 1 0}$ & $\mathbf{6 2 , 9 6 5 , 3 8 4 . 7 0}$ \\
\hline
\end{tabular}

Source: http://arf.gov.ro/web/wp-content/uploads/2019/10/Octombrie-2019-Studiuanaliza-indicatori-OTF, p. 7

As a result of this diminution, railway operators had been forced to reduce the numbers of the train they used, and in some cases, some of them had to completely abandon specific portions of un-interoperable sections of circulation.

\section{The evolution of passengers-km indicator}

We can observe an important increase of passengers-km indicator in 2017 after Romania's Government decided to allot transport facilities for students using metro and trains.

Table 3. The Evolution of Passenger-Km Indicator for 2016-2018

\begin{tabular}{|l|r|r|r|}
\hline \multicolumn{1}{|c|}{ Transport Railway Operator } & $\mathbf{2 0 1 6}$ & $\mathbf{2 0 1 7}$ & \multicolumn{1}{c|}{$\mathbf{2 0 1 8}$} \\
\hline SNTFC CFR CALATORI & $52,898,759$ & $56,927,403$ & $53,738,628$ \\
\hline REGIOTRANS & $5,961,396$ & $5,861,407$ & 0 \\
\hline REGIO CALATORI & 0 & 347,81 & $6,230,398$ \\
\hline TRANSFEROVIAR CALATORI & $4,350,010$ & $4,536,842$ & $4,745,940$ \\
\hline INTERREGIONAL CALATORI & 940,675 & 998,474 & $1,323,221$ \\
\hline ASTRA TRANS CARPATIC & 0 & 0 & 162,475 \\
\hline SOFTRANS TOTAL & 326,757 & 359,209 & 311,924 \\
\hline \multicolumn{1}{|c|}{ TOT, } & $\mathbf{6 4 , 4 7 7 , 5 9 7}$ & $\mathbf{6 9 , 0 3 1 , 1 4 5}$ & $\mathbf{6 6 , 5 1 2 , 5 8 6}$ \\
\hline
\end{tabular}

Source: http://arf.gov.ro/web/wp-content/uploads/2019/10/Octombrie-2019-Studiuanaliza-indicatori-OTF, p. 8 
Main private railway transport companies moving passengers have registered an increase of send travelers in 2016-2018 period related to public railway operator SNTCF CFR Calatori, which had registered a decline on this indicator in 2018 related to 2017, especially due to shortages in rolling material area, overlapping its decision to reduce its number of trains in use, as a consequence of decision regarding the public financing reduction.

\section{The evolution of trains in use}

Observing the precedent tables regarding the number of operated trains and send passengers, the five private railway operators in comparison with the public operator, registered an increase of send passengers

Table 4. The Evolution of Trains in Use Indicator for 2016-2019 Period

\begin{tabular}{|l|r|r|r|r|}
\hline \multicolumn{1}{|c|}{ OTF } & \multicolumn{1}{c|}{$\mathbf{2 0 1 6}$} & \multicolumn{1}{c|}{$\mathbf{2 0 1 7}$} & \multicolumn{1}{c|}{$\mathbf{2 0 1 8}$} & \multicolumn{1}{c|}{$\mathbf{2 0 1 9}$} \\
\hline SNTFC CFR CALATORI & 409,224 & 414,329 & 394,775 & 381,527 \\
\hline REGIOTRANS & 85,698 & 80,821 & & \\
\hline REGIO CALATORI & & 5,071 & 89,421 & 86,317 \\
\hline TRANSFEROVIAR CALATORI & 47,896 & 48,149 & 43,896 & 43,876 \\
\hline INTERREGIONAL CALATORI & 17,425 & 23,024 & 23,720 & 27,904 \\
\hline ASTRA TRANS CARPATIC & & & 1,655 & 3,472 \\
\hline SOFTRANS & 3,149 & 3,438 & 2,067 & 1,674 \\
\hline TOTAL GENERAL & $\mathbf{5 6 3 , 3 9 2}$ & $\mathbf{5 7 4 , 8 3 2}$ & $\mathbf{5 5 5 , 5 3 4}$ & $\mathbf{5 4 4 , 7 7 0}$ \\
\hline
\end{tabular}

Source: http://arf.gov.ro/web/wp-content/uploads/2019/10/Octombrie-2019-Studiuanaliza-indicatori-OTF p. 9

Even they registered a reduction in train-km indicator, after they had taken measures to optimize the use of their available rolling material, rising the degree of occupancy rate for their trains in use.

Table 5. The Evolution of send passenger' numbers/operated trains 2016-2018

\begin{tabular}{|l|c|c|c|}
\hline \multicolumn{1}{|c|}{ OTF } & $\mathbf{2 0 1 6}$ & $\mathbf{2 0 1 7}$ & $\mathbf{2 0 1 8}$ \\
\hline SNTFC CFR CALATORI & 129.27 & 137.40 & 136.12 \\
\hline REGIOTRANS & 69.56 & 72.52 & 0 \\
\hline REGIO CALATORI & 0 & 68.59 & 69.67 \\
\hline TRANSFEROVIAR CALATORI & 90.82 & 94.23 & 108.12 \\
\hline INTERREGIONAL CALATORI & 53.98 & 43.37 & 55.79 \\
\hline ASTRA TRANS CARPATIC & 0 & 0 & 98.17 \\
\hline SOFTRANS TOTAL & 103.77 & 104.48 & 150.91 \\
\hline \multicolumn{1}{|c|}{ The } & $\mathbf{4 4 7 . 4 0}$ & $\mathbf{5 2 0 . 5 8}$ & $\mathbf{6 1 8 . 7 8}$ \\
\hline
\end{tabular}

Source: http://arf.gov.ro/web/wp-content/uploads/2019/10/Octombrie-2019-Studiu-analizaindicatori-OTF, p. 10

It is important to mention that companies whose activity is focused on operating trains with rank Interregio (longer distances) had registered higher value than those operating trains of Regio rank (short distances). 
Table 6. The evolution of send passengers/exploited km (2016-2018)

\begin{tabular}{|l|c|c|c|}
\hline Transport operator & $\mathbf{2 0 1 6}$ & $\mathbf{2 0 1 7}$ & $\mathbf{2 0 1 8}$ \\
\hline SNTFC CFR CALATORI & 1,01 & 1,09 & 1,08 \\
\hline REGIOTRANS & 0.99 & 1,04 & 0,00 \\
\hline REGIO CALATORI & 0,00 & 1,06 & 1,01 \\
\hline TRANSFEROVIAR CALATORI & 1,33 & 1,33 & 1,38 \\
\hline INTERREGIONAL CALATORI & 0.81 & 0.69 & 0.89 \\
\hline ASTRA TRANS CARPATIC & 0,00 & 0,00 & 0.27 \\
\hline SOFTRANS & 0.51 & 0.56 & 0.57 \\
\hline TOTAL & $\mathbf{4 , 6 6}$ & $\mathbf{5 , 7 8}$ & $\mathbf{5 , 2 0}$ \\
\hline
\end{tabular}

Source: http://arf.gov.ro/web/wp-content/uploads/2019/10/Octombrie-2019-Studiu-analizaindicatori-OTF, p. 11

Transport operators mainly activating trains ranking in Regio classification on un-interoperable (secondary) lines, had registered much higher values for this index related to companies that activate Interregio trains on interoperable lines (main lines). As a matter of fact, InterRegio trains (IR) stop in middle and great cities, while Regio trains (R) stop in all train stations, even in the smallest.

\section{EXPENDITURES AND INCOMES REGISTERED BY RAILWAY OPERATORS DURING 2016-2019}

Table 7. The Evolution of average cost (RON)/used kilometer indicator for 2016-2019

\begin{tabular}{|l|c|c|c|c|}
\hline OTF & $\mathbf{2 0 1 6}$ & $\mathbf{2 0 1 7}$ & $\mathbf{2 0 1 8}$ & $\mathbf{2 0 1 9}$ \\
\hline SNTFC CFR CALATORI & 39.47 & 43.20 & 46.63 & 52.43 \\
\hline REGIOTRANS & 28.03 & 29.11 & & \\
\hline REGIO CALATORI & & 35.04 & 28.05 & 32.53 \\
\hline TRANSFEROVIAR CALATORI & 30.71 & 32.80 & 31.60 & 31.47 \\
\hline INTERREGIONAL CALATORI & 24.11 & 25.98 & 25.29 & 25.45 \\
\hline ASTRA TRANS CARPATIC & & & 34.74 & 34.05 \\
\hline SOFTRANS & 28 & 30.03 & 32.23 & 31.72 \\
\hline
\end{tabular}

Source: http://arf.gov.ro/web/wp-content/uploads/2019/10/Octombrie-2019-Studiuanaliza-indicatori-OTF, p. 13

There had been registered a steady increase of costs/used $\mathrm{km}$ in the case of SNTCF CFR Calatori, a public railway operator, in comparison with other private operators, which registered relatively stable costs.

Table 8. The Evolution of Average Income (RON/km) during 2017-2019 for Trains Ranked as Regio

\begin{tabular}{|l|c|c|c|}
\hline \multicolumn{1}{|c|}{ OTF } & 2017 & 2018 & 2019 \\
\hline SNTFC CFR CALATORI & 4.23 & 5.03 & 5.58 \\
\hline REGIOTRANS & 0 & 5.41 & 0 \\
\hline REGIO CALATORI & 5.75 & 5.37 & 5.51 \\
\hline TRANSFEROVIAR CALATORI & 5.63 & 6.24 & 5.10 \\
\hline INTERREGIONAL CALATORI & 2.51 & 4.33 & 0 \\
\hline ASTRA TRANS CARPATIC & 0 & 0 & 0 \\
\hline
\end{tabular}




\begin{tabular}{|l|c|c|c|}
\hline SOFTRANS & 1.68 & 1.46 & 0 \\
\hline
\end{tabular}

Source: http://arf.gov.ro/web/wp-content/uploads/2019/10/Octombrie-2019-Studiu-analizaindicatori-OTF, p. 24

For 2017-2019 period the highest average incomes for trains ranking in Regio category were registered by Transferoviar Calatori SRL and Regio Calatori SRL.

Table 9. The Evolution of Average Income (RON/km) during 2017-2019 for Trains Ranked as InterRegio

\begin{tabular}{|l|c|c|c|}
\hline \multicolumn{1}{|c|}{ OTF } & 2017 & 2018 & 2019 \\
\hline SNTFC CFR CALATORI & 28.65 & 41.48 & 41.58 \\
\hline REGIOTRANS & 7.89 & 0 & 0 \\
\hline REGIO CALATORI & 0 & 9.50 & 15.46 \\
\hline TRANSFEROVIAR CALATORI & 10.40 & 11.24 & 16.30 \\
\hline INTERREGIONAL CALATORI & 3.24 & 0 & 0 \\
\hline ASTRA TRANS CARPATIC & 0 & 14.95 & 12.81 \\
\hline SOFTRANS & 14.04 & 16.10 & 14.70 \\
\hline
\end{tabular}

Source: chttp://arf.gov.ro/web/wp-content/uploads/2019/10/Octombrie-2019-Studiu-analizaindicatori-OTF p. 25

For 2017-2019 period the highest average incomes for trains ranking in Interregio category were registered by SNTCF CFR Calatori SA.

\section{Perspectives: potential for development}

The analysis of performance parameters in need for providing a competitive railway transport at the national level points to the idea that there is possible a rehabilitation and revitalization of passengers railway transport; there manifests at the domestic market level a great degree of expectancies on customers' part, and this is because of:

- demand for public transport directly depends on the domestic economy's evolution, and as economic trends indicate, there could manifest a rising demand for transport services in the period ahead;

- lack of attractiveness and competitiveness of Romanian railway system is reversible, as we can observe from the evolution of operators capable to offer performing and suitable services in accordance with customers' expectancies.

Graph 2. The Rising Potential for Railway Transport of Passengers

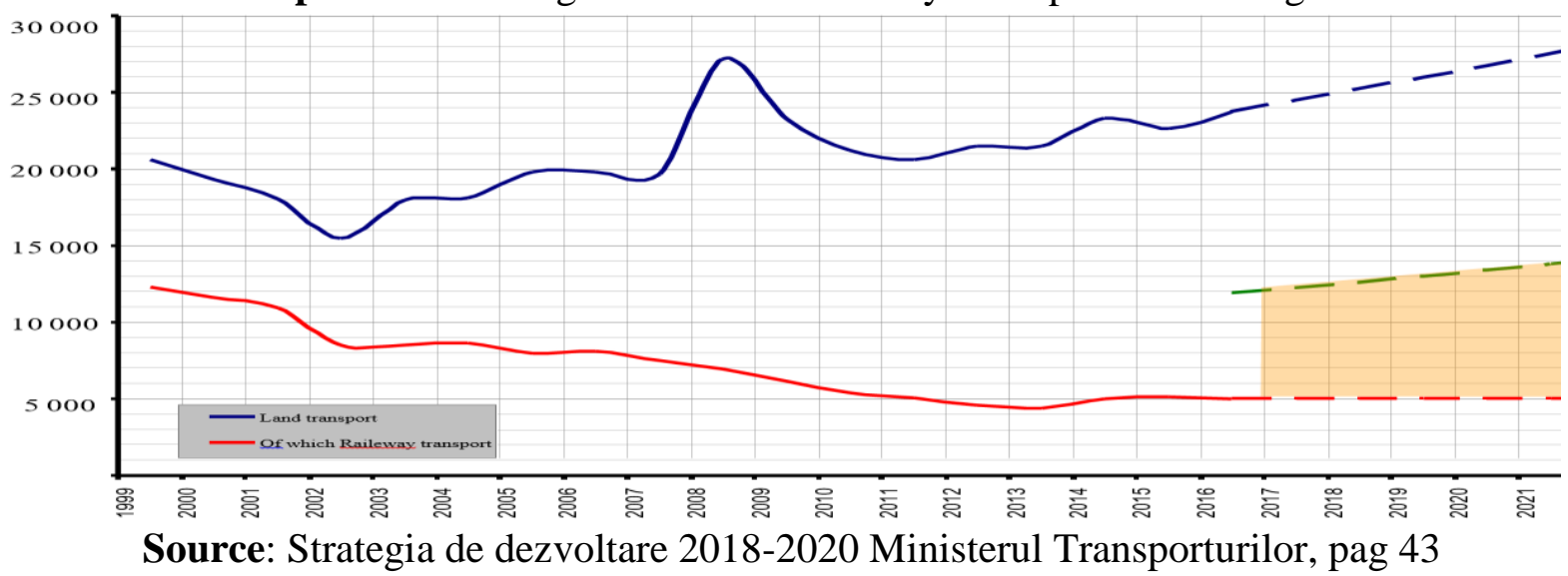


This graph indicates that there is a potential increase in the number of passengers transported on railways in Romania, based on the assumption there would be registered a trend of economic development in the future. As a consequence, the existence of room for future development could justify the employment of supplementary efforts, but there should be considered some specific actions first.

In order to develop passengers railway transport, there must:

- be provided a higher amount of public money directed to railways, in comparisons with allowances directed to road transport sector;

- be ensured a higher level o performance for trains circulation, from both commercial speed point of view and of punctuality;

- promote of specific services characterized by higher frequency;

- promote high-speed railway transport;

- provision of higher accessibility to and from train stations;

- be ensured a higher level of quality of services in train stations, and on board;

- maintain and develop supplementary projects in order to create a dense railway network.

The rising demand for population mobility is more than obvious, which is due to both technological evolution and population's incomes, and it is triggered by the necessity to provide higher efficacy on the labor market. The society which will move faster can gain more: in this framework, it is needed the implementation modes of transport which can move together more passengers in a time unit using the most efficient types of transport.

Railway transport must become a major component for making trips, on short and medium distances, but for longer distances, too. It will come as a sustainable solution for road infrastructure's decongestion, with all advantages related to transport and environmental costs.

It must be arranged suburban railway transport in important metropolitan areas, in connection with its integration with the urban public transport system, in order to provide comfortable and affordable intermodal transport.

Rising accessibility for train stations through efficient intermodal interfaces related to other types of transport, including privately owned cars (which means parking places available close to train stations) can become part of the solution aiming at rising railway attractiveness.

At the international level, there must be a consolidated international railway transport in order to provide attractive services for passengers who want to travel on long distances; higher speed trains with higher accessibility, because train stations are constructed especially inside the cities, can become a source of higher competitiveness face-to-face with airway transport. As sitting at an important crossroads, Romania can promote the development of longer-distance transport on railways, facilitating in this way the connection between Central Europe and Black Sea, and Northern Europe to Istanbul. This will transform Romania into an important hub in the European transport network.

\section{CONCLUSION}

It is absolutely necessary to consolidate public passengers railway transport services in order to provide the framework for a viable and attractive alternative to road transport using privately owned cars, which would contribute immediately to reducing road infrastructure overloading, rising the flow on national roads; this would bring lower pollution, higher economic efficiency 
at domestic level, smaller risk of accidents.

\section{REFERENCES}

CFR Calatori, http://www.consiliulferoviar.ro/; Studiu de piaţă în transportul de călători Development strategy 2018-2020, Ministry of Transport, Bucharest, Romania

Gherasim T. (2007) Sisteme de transport, Transporturi feroviare, Editura Bacovia, Bacău, Romania

Railway Handbook (2014) - Energy Consumption and CO2 Emissions - Focus on Infrastructure European Environment Agency

Studiu-analiză-inicatori-OTF, Autoritatea de Reformă Feroviară http://arf.gov.ro/web/wpcontent/uploads/2019/10/Octombrie-2019-Studiu-analiza-indicatori-OTF 